\title{
SCALE RESPONSE OF SUMMER URBAN HEAT ISLAND TO BUILDING PLOT RATIO AND ITS WARNING PARAMETER
}

\author{
Huanchun Huang, Yingxia Yun, Jiangang Xu, Rong Huang, Jing Fu, Kaidi Huang
}

Original scientific paper Plot ratio is an important indicator of architectural layout that affects urban heat island (UHI). Previous studies focus on street height/weight ratio, building density, and other indicators related to plot ratio but fail to effectively describe the time-space relationship between plot ratio and UHI and accurately guide the planning and design to reduce the UHI in the effective scale. The scale sensitivity method was proposed to study the time-space response of UHI to plot ratio to control the UHI intensity (UHII) caused by plot ratio during planning and design in a reasonable scale. The sensitivity of plot ratios in different space scales to UHI in the daytime was repeatedly calculated on 3S technology, MATLAB, SPSS, and other data analysis platforms based on the scale theory of landscape ecology and the method of geo-statistics analysis. The change curve of the response of plot ratio on UHI in the most sensitive space scale was discussed. The prevention and control standard of summer UHI was then constructed in accordance with the temperature in dog days of summer, human physiological reaction under high temperature, and relevant national regulations. The warning control was taken on the parameters of plot ratio on the basis of the temperature rise of UHI caused by plot ratio. Results show that scale sensitivity exists between plot ratio and UHI. In the daytime, the relationship between core plot ratio and summer UHI shifts from negative correlation to positive correlation. The temperaturerising effect in the afternoon is greater than the cooling effect in the morning. Core plot ratio has a linear relationship with summer UHII. The increase in the average core plot ratio reduces the UHII by $0,76{ }^{\circ} \mathrm{C}$ in the morning and increases it by $0,97{ }^{\circ} \mathrm{C}$ in the afternoon. The optimal sensitive radius of the core plot ratio on summer UHI is $230 \mathrm{~m}$. The response mechanism of plot ratio on UHI is mainly due to heat storage volume and block to radiation heat. The study conclusion can provide scientific theoretical parameter support for architectural design and urban planning and design.

Keywords: core plot ratio; scale sensitivity; summer; UHII; warning parameter

Reakcija urbanog toplinskog otoka ljeti na omjer građevne čestice i njezin parametar upozorenja

Izvorni znanstveni članak Omjer građevne čestice je značajan pokazatelj arhitektonskog rasporeda koji utječe na urbani toplinski otok (UHI - urban heat island). Prethodna su istraživanja usredotočena na omjer visina/težina, gustoću zgrada i ostale pokazatelje povezane s omjerom građevne čestice, ali ne uspijevaju uspješno opisati odnos vrijeme-prostor između omjera građevne čestice i UHI te točno voditi planiranje i projekt kako bi se smanjila učinkovitost UHI-a. Metoda stupnja osjetljivosti predložena je za analiziranje reakcije vrijeme-prostor UHI-a na omjer građevne čestice u svrhu reguliranja intenziteta UHI (UHII) do kojeg je došlo prihvatljivim omjerom građevne čestice tijekom planiranja i projektiranja. Osjetljivost omjera građevnih čestica u različitim prostornim omjerima prema UHI tijekom dana izračunata je redom pomoću 3S tehnologije, MATLABa, SPSS-a i drugih platformi zasnovanih na teoriji razmjere ekologije pejzaža i metodi geo-statističke analize. Razmatrana je krivulja promjene reakcije omjera građevne čestice na UHI u najosjetljivijoj prostornoj ljestvici. Tada je izrađen standard prevencije i kontrole UHI-a ljeti prema temperaturi tijekom najtoplijih ljetnih dana i ljudskoj fiziološkoj reakciji kod visokih temperatura, i odgovarajućim nacionalnim pravilima. Dano je upozorenje na parametre omjera građevne čestice na temelju porasta temperature UHI-a zbog omjera građevne čestice. Rezultati pokazuju da postoji skala osjetljivosti između omjera građevne čestice i UHI. Po danu se odnos između osnovnog omjera građevne čestice i ljetnog UHI-a pomiče od negativne ka pozitivnoj korelaciji. Učinak porasta temperature poslije podne veći je od jutarnjeg rashlađenja. Osnovni omjer građevne čestice je u linearnom odnosu s ljetnim UHII. Povećanje prosječnog omjera čestice dovodi do smanjenja UHI za $0,76{ }^{\circ} \mathrm{C}$ ujutro i porasta za $0,97{ }^{\circ} \mathrm{C}$ poslije podne. Optimalni radijus osjetljivosti omjera građevne čestice na ljetni UHI iznosi $230 \mathrm{~m}$. Mehanizam reakcije omjera građevne čestice na UHI nastaje uglavnom zbog obujma pohranjene topline i zaustavljanja topline zračenja. Zaključak ove analize može pružiti podršku znanstveno teoretskom parametru u arhitektonskom dizajnu i urbanom planiranju i dizajnu.

Ključne riječi: ljeto; osnovni omjer građevne čestice; parametar upozorenja; stupanj osjetljivosti; UHII

\section{Introduction}

Urban heat island (UHI) is a phenomenon in which the temperature in urban areas is higher than that in rural areas [1]. This phenomenon is mainly due to the fact that the original natural landscape with vegetation in urban areas is replaced by the closely-packed artificial buildings with high heat storage capacity. The acceleration of the world urbanization in recent years has rapidly increased the UHI intensity (UHII) and UHI area [2]. The UHI problem caused by urban architectural layout has posed a serious threat on the safety of the living environment in summer [3]. Building plot ratio is an important index for urban planning to control the environment in the built-up area. The rapid urban expansion has made the UHI a major urban environmental problem, which must be solved to simulate the temperature rise of summer UHI using the urban-planning scheme and thus reduce the harm of UHI to the public health and living environment.

The previous studies on UHI caused by urban architecture layout focus mainly on building density, street height/width ratio, and ventilation corridor $[4 \div 6]$, which are indirectly related to plot ratio. Although the geographical position of a city has certain influence on UHI [7, 8], from the urban energy balance, the temperature rise of UHI is mainly due to the increase in radiation absorbed by buildings, the reduction in reflection energy, and the increase in anthropogenic heat emissions. The ground objects that are adjacent in space within a certain scale typically influence one another, but previous studies do not reflect the relationship degree between building capacity layout and UHI in different scales. Therefore, the selection of an appropriate space and the clarification of the influence of plot ratio on UHII are important theoretical issues to model the relationship between UHI and plot ratio.

This study analysed the theoretical relation model about the scale response of summer UHI to building plot ratio through algorithms and model construction in the daily variation cycle of summer UHI based on the scale concept theory of landscape ecology to solve the abovementioned problem. A warning system, based on plot 
ratio, was proposed to prevent and control UHI through multiple composite UHI control standards.

\section{State of the art}

Considerable number of literature references show that architecture layout adjustment is a promising measure to reduce UHI $[9,10]$. The influence of architecture layout on UHI is reflected by heat storage, heat flow, and conversion between sensible heat and latent heat. Plot ratio and building density are two relevant indexes of architecture layout. They both have important effects on UHI in the urban built-up areas. The study of this problem can be divided into two aspects, namely, surface UHI and near-surface atmospheric UHI [11, 12]; however, the study conclusions of the two aspects obviously differ.

The surface UHI produced by the plot ratio and density of architecture layout is often studied by the remote-sensing method. Hamdi regarded Basel as an example in investigation and found that UHII is correlated with streets and sizes of buildings in cities and that an effective test space must consider the shades and radiation of buildings [13]. Therefore, the study scope can affect the result. The article does not elucidate this problem. Yunhao studied the radiation temperature variation of south, east, and west walls in the daily changing cycle [14], indicating that the architecture layout indicators affect the changing characteristics of the spatial pattern of UHI. Chun explored the relationship between 2D and 3D forms and UHI in central cities through remote-sensing images [15]. The results show that the UHII increases with the increase of building density, but the study also fails to pay attention to the change in the time scale. Yaning analysed the correlation between building density and UHI and its change. The results show that surface temperature is positively correlated with building density; great building density leads to high average surface temperature [16]. The conclusion is clearly limited by satellite data. The finding can only be valid at 10:30 am local time but cannot represent the relationship between UHI and building density at all times during the day. Nassar considered Dubai as a case to study the phenomenon of collection and island of UHI by remote sensing. The study shows that the open, high-rise urban area exhibits a good cooling effect, and building height and shadow influence UHI [17]. The conclusion again suggests the close relationship between plot ratio and UHI Thus, the UHI study results by satellite images in recent decades have clearly proven that building plot ratio and UHI present correlation and scale variation characteristics $[18 \div 20]$. Many problems still need to be discussed. Conclusions can only be valid in specific periods of time but cannot be applied to other times in the day. Significant study also has combined building density and plot ratio.

Studies related to near-surface atmospheric UHI near ground have mostly adopted actual measurement to accurately acquire the standard temperature at $1.5 \mathrm{~m}$ in real time [21]. Buildings exert influence on UHI through energy consumption and heat emission [22] and change the outdoor temperature through heat storage and shade. Oke and Stewart introduced the concept of local climate zone, which makes divisions depending on building height and space, vegetation density, and soil humidity to ensure accurate and targeted study on UHI [23]. However, this method integrates various ground objects without single analysis on the influence of building plot ratio on UHI. Radhi studied Bahrain Islands through simulation and found that the UHI caused by buildings can be enhanced by $5{ }^{\circ} \mathrm{C}$ [24], but he did not give the simulation results of the UHI caused by specific indicators of architectural layout. Bakarman found through observation that building height/width ratio is an important factor affecting UHI in the tropics within the urban micro climate scale in the urbanization process [25]. This observation indicates that building volume is related to UHI and should be considered in the study of the relationship between building plot ratio and UHI. Actual air temperature testing reveals that the radius of the most sensitive scale between building density and UHI in the daytime is $130 \mathrm{~m} \mathrm{[26].} \mathrm{The} \mathrm{UHII} \mathrm{is} \mathrm{mainly} \mathrm{reduced.} \mathrm{Thus,}$ a sensitive scale between building density and relevant plot ratio must be developed. Considering that analysing space correlation and scale sensitivity is impossible due to the small number of observation stations in most UHI studies based on station data, studies have focused on the seasonal, daily, and annual variation characteristics of UHI [27-30]. Existing literature shows that building plot ratio and UHI change over time. Nevertheless, comprehensive understanding of the closest scale of summer UHI to plot ratio, as well as the interactive characteristics between them over time in the daily variation cycle and the prevention and control parameters, is needed to conduct UHI simulation and planning application.

Therefore, this study arranged 18 monitoring points by ArcGIS and ENVI software and adopted the synchronous recording data of temperature and humidity by $3 \mathrm{~S}$ technology, high-precision map, and high-precision testing instrument to construct a theoretical relationship model of the scale sensitivity of summer UHI to plot ratio through MATLAB and SPSS software platforms. Through clarifying the law characteristics of UHI and building layout in the daily variation cycle, this study then provided the corresponding warning parameters for prevention and control in accordance with the theoretical model and UHI control standard to provide feasible ways to prevent and control UHI during urban planning and construction.

The remainder of the paper is organized as follows. Section 3 defines the calculation method of UHII, introduces the conceptual algorithm of core plot ratio, and constructs the algorithm of scale sensitivity. Section 4 analyses the scale sensitivity, hourly variation characteristics, and action mechanism of building plot ratio on UHI, clarifies the functional relationship between core plot ratio and UHII, and proposes the early warning parameters of plot ratio to control UHI. Finally, Section 5 elaborates the conclusions of the study.

\section{Methodology}

\subsection{Calculation method of UHII}

The difference between the temperature of the urban area and that of the suburbs is defined as UHII in this study [31]. UHII can be calculated by different methods 
$[32 \div 34]$. Then, the temperature difference between a spatial position in the city and the suburbs at a certain time is defined as the UHII of that particular position. The calculation formula is

$\Delta T_{i j}=T_{i j}-T_{R}$

where $\Delta T_{i j}$ is the UHII at the spatial position $i j, T_{i j}$ is the surface temperature at the spatial position $i j$, and $T_{R}$ is the temperature in the suburbs. This study adopts the mutual checking method between actual measurement in the suburbs and the data recorded by international meteorological observation points.

\subsection{Kernel density estimation method}

Density is a field expression of the space phenomenon. This field expression is determined by the relationship between adjacent spatial positions. The calculation method of kernel density is based on the first law of geography, which holds that contiguous things are closely related. As a highly accurate analysis tool, the kernel density method can dig the deep characteristic and law information of the spatial characteristic distribution and verify the gathered or regular spatial distribution characteristics, such as urban area description and environmental space distribution analysis [35].

The principle of the kernel density estimation method is to take $P$ as the centre of the circle and the threshold value $r$ as the radius to collect the number of information variables in the circle composed by $P$ and $r$ and divide the number by the area of the circle. The kernel density with $P$ as the centre of the circle can generally be calculated by the following formula:

$$
p(x)=\frac{1}{n h^{d}} \sum_{i=1}^{n}\left\{K\left[\frac{d\left(x, x_{i}\right)}{h}\right]\right\}
$$

where $n$ represents the amount of ground object information in the distance scale; $K()$ represents the kernel density function; $h$ is the distance threshold value, namely, the scale of the kernel density estimation method; $d\left(x, x_{i}\right)$ expresses the Euclidean distance between two points. Several studies have shown that the threshold value $h$ has an important influence on the kernel density analysis and results. In other words, this value is the appropriate space scale.

\subsection{Scale sensitivity 3.3.1 Concept of scale}

Scale refers to the time unit and spatial resolution of an object or process [36], and it is a pattern change determined by the time-space range. Scale specifies the inherent characteristics or laws of the things in nature and is expressed and demonstrated by humans or other creatures.

Scale can be divided into three categories, namely, time, space, and organization scale. Operation scale, also called organization scale, refers to the space range where a geological process or phenomenon occurs. This scale is determined by the nature of the study object and not affected by man-made interferences, such as the pattern, process, and scale effect produced by the underlying surface building layout and UHI.

\subsubsection{Theoretical basis of scale sensitivity}

The scale effect is common in nature and social sciences. The rule in a scale is unnecessarily effective in another scale [37, 38], the same as that in UHI. For a number of studies, the scale in the final analysis is to use the most appropriate space, time, and organization scale to express the characteristics and laws of the things themselves through proper methods and thus ease the measurement and calculation. The most appropriate scale is the most sensitive scale.

Scale sensitivity is actually the reflection of the law of geography. Regionalized variable reflects the randomness, structure, and space limitation of the space phenomenon. Structure means that a certain autocorrelation exists between $Z(x)$ and $Z(x+h)$ of the variable at Points $x$ and $x+h$ deviating from the space distance $h$, and the autocorrelation degree depends on the distance $h$ between two points. Space limitation is the reflection of spatial correlation among variables. Within a certain range, when the distance $h$ between two sampling points increases to $h>r$, no spatial correlation exists. For example, UHI is the regionalized variable. They are no longer correlated beyond a certain distance. Within a certain distance, a factor is the most sensitive.

\subsubsection{Measure of scale sensitivity}

This study focuses mainly on the spatial scale sensitivity of core plot ratio to UHI, namely, the space scale that can best show the influence of plot ratio on UHI The relationship between building plot ratio and UHI is characterized by hourly variation, and the relevant coefficients reflect the influence on UHII in different space-time scales. Therefore, the scale sensitivity index in this study adopts the absolute value. Its computation formula is

$$
S=\sum_{i=1}^{n}\left|\frac{\sum_{i=1}^{n}\left(x_{i}-\bar{x}\right)\left(y_{i}-\bar{y}\right)}{\sqrt{\sum_{i=1}^{n}\left(x_{i}-\bar{x}\right)^{2}} \sqrt{\sum_{i=1}^{n}\left(y_{i}-\bar{y}\right)^{2}}}\right|
$$

where $S$ is the scale sensitivity value, $n$ is the different testing times of UHI, $\bar{x}$ and $\bar{y}$ are the average values of two element samples, $x_{i}$ and $y_{i}$ are the values of the $i^{\text {th }}$ element of two element samples.

Scale sensitivity index $S$ reflects the influence degree of UHI to plot ratio in specific scale. The influence of plot ratio on UHI at the central point is different within different radii. Small scale indicates a small number of relevant factors, and large scale involves irrelevant ground objects in calculation, thereby increasing the error in both scales. Thus, the optimal radius exists, namely, the most sensitive scale, in which the action mechanism and law on UHI can be best reflected. 


\subsection{Case study area}

Tianjin is located in the north of the north China plain, with the Bohai Sea to its east and Yanshan to its north. This area is across both sides of the Haihe River. The area expanded from $280 \mathrm{~km}^{2}$ in 1992 to $1006 \mathrm{~km}^{2}$ in 2014 due to the rapid urbanization in the recent 20 years. In the same period, the urban construction developed rapidly, and the original low-rise high-density buildings were also replaced by a large number of multilayer and high-rise buildings. At the end of 2012, the area of all building types reached 354,8598 million $\mathrm{m}^{2}, 34,61 \mathrm{~m}^{2}$ per capita. However, UHI became increasingly serious. The surface UHII during 1992 and 2014 increased from $8,55{ }^{\circ} \mathrm{C}$ to
$12.47{ }^{\circ} \mathrm{C}$. An incomplete test in 2013 indicated that the local UHI air temperature was more than $6{ }^{\circ} \mathrm{C}$.

As a representative city, Tianjin reflects the rapid increase in building area, building volume, and plot ratio in the rapid urbanization in China. These indexes become the main factors that result in UHI rise. Thus, the relationship between the plot ratio of the main urban area and UHII in Tianjin is typically studied. The current study area covers most of the city center (Fig. 1), that is, entire Heping District, Hedong District, Hebei District, Hongqiao District, Nankai District, and most of Hexi District. The total area is $316 \mathrm{~km}^{2}$, and the plot ratio varies from 0,08 to 3,56 . The permanent population in the region was 3,9462 million by the end of 2013 , which was approximately $72,04 \%$ of the urban population.

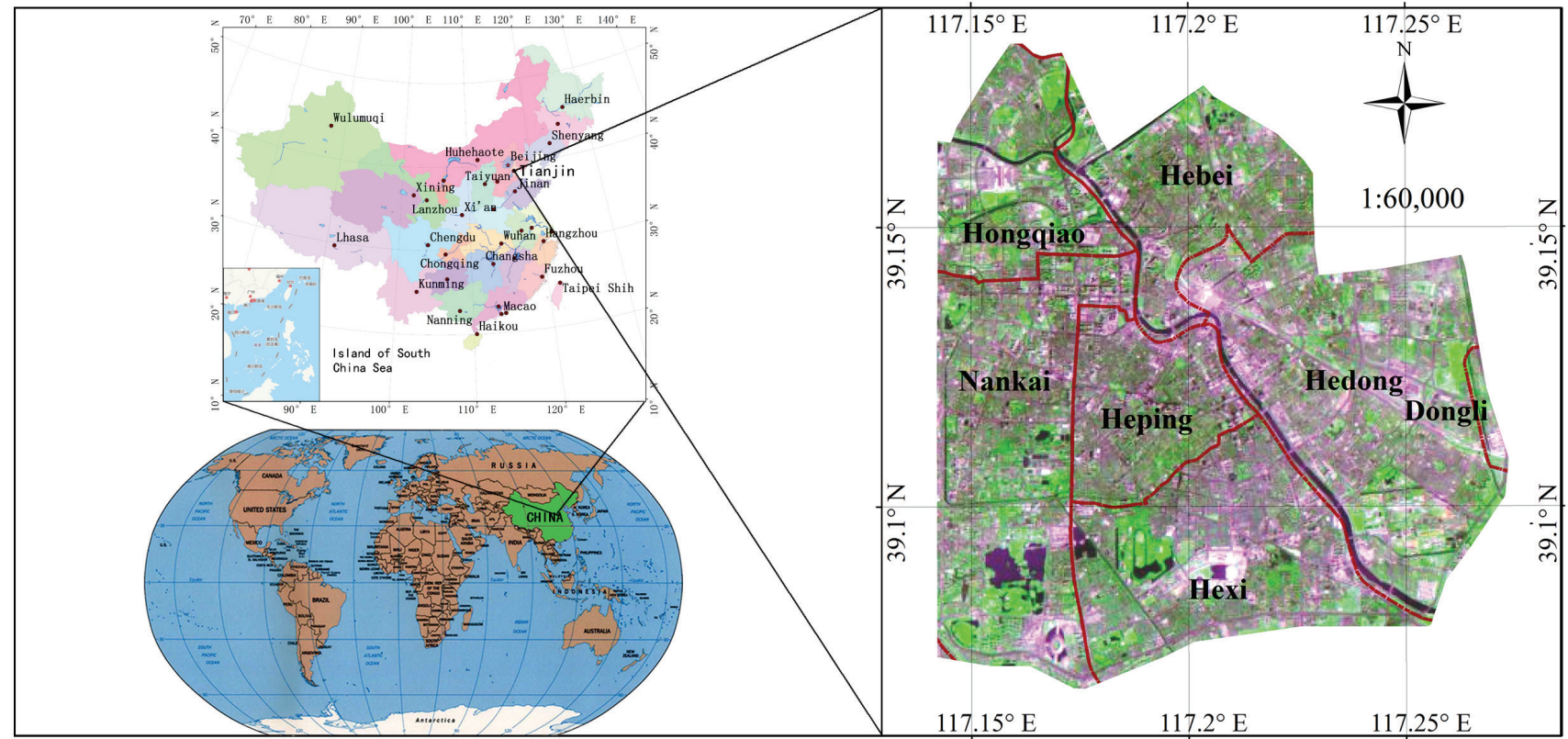

Figure 1 Study area

\subsection{Study data}

\subsubsection{Data selection criteria}

The data collection and processing criteria in this study prevented the disadvantages of low data accuracy, small number of monitoring points, and insufficient space layout samples. The test was conducted in the daytime during July 7 and August 7, 2013. Although UHII is weak in the daytime, UHI is the most harmful in summer daytime. The meteorological conditions in the study period must abide by the following three points. First, the UHI observation should avoid the influence of rain because large amounts of precipitation have an obvious impact on UHI. Second, the observation must be conducted in the sunny and cloudy days because the UHII in the sunny day is higher than that in the grey day (the meteorological records in the same period show that the sunny and cloudy days account for $75 \%$ of the entire summer in Tianjin). Third, the average wind speed should be close to $2,6 \mathrm{~m} / \mathrm{s}$ because the wind speed significantly affects the UHII (the meteorological records show that the average wind speed in the sunny and cloudy days in Tianjin is $2,6 \mathrm{~m} / \mathrm{s}$ over the years).

\subsubsection{Data collection and processing}

Pléiades high-resolution images on July 16, 2013 were adopted in accordance with the data selection criteria. The spatial resolution is 0,5 m. 1:2000 map and the master plan of Tianjin in 2013 was paired with them. The data received accurate geometric correction first to control the pixel error within $0,5 \mathrm{~m}$. Instrument errors are calculated according to the maximum error. They were then projected as WGS 1984 UTM $50 \mathrm{~N}$ uniformly to maintain the data consistency. Finally, the GIS database was established.

Monitoring point selection involved spatial uniformity and data distribution of the samples with different plot ratios. A model was constructed in ArcGIS software to calculate the spatial distribution of plot ratios (Fig. 2b). The calculation principle is presented in Section 3.2. The plot ratios were then equidistantly divided into 17 levels. A total of 18 monitoring points were arranged in urban areas and 6 in the suburbs, thereby obtaining 24 monitoring points (Fig. 2)

Temperature and humidity were tested according to the international standard. The thermometer shelters were supported by steel brackets, and the recording instruments were $1,5 \mathrm{~m}$ above the ground. Huato high-precision 
HE174 type was used to automatically record the temperature and humidity data every $5 \mathrm{~min}$. The humidity error was controlled within $\pm 2 \%$ and the temperature error within $\pm 0,3{ }^{\circ} \mathrm{C}$. The temperature recording of the instrument followed the principle of thermal resistor. The coordinates of monitoring points were recorded by the US
GPS coordinate MobileMapper10, with an accuracy of $\pm 0,5 \mathrm{~m}$. No tall buildings or trees were found around the test points. Certain distance was kept between test points and buildings or structures. The influence of vehicle exhaust on the roads was also avoided.

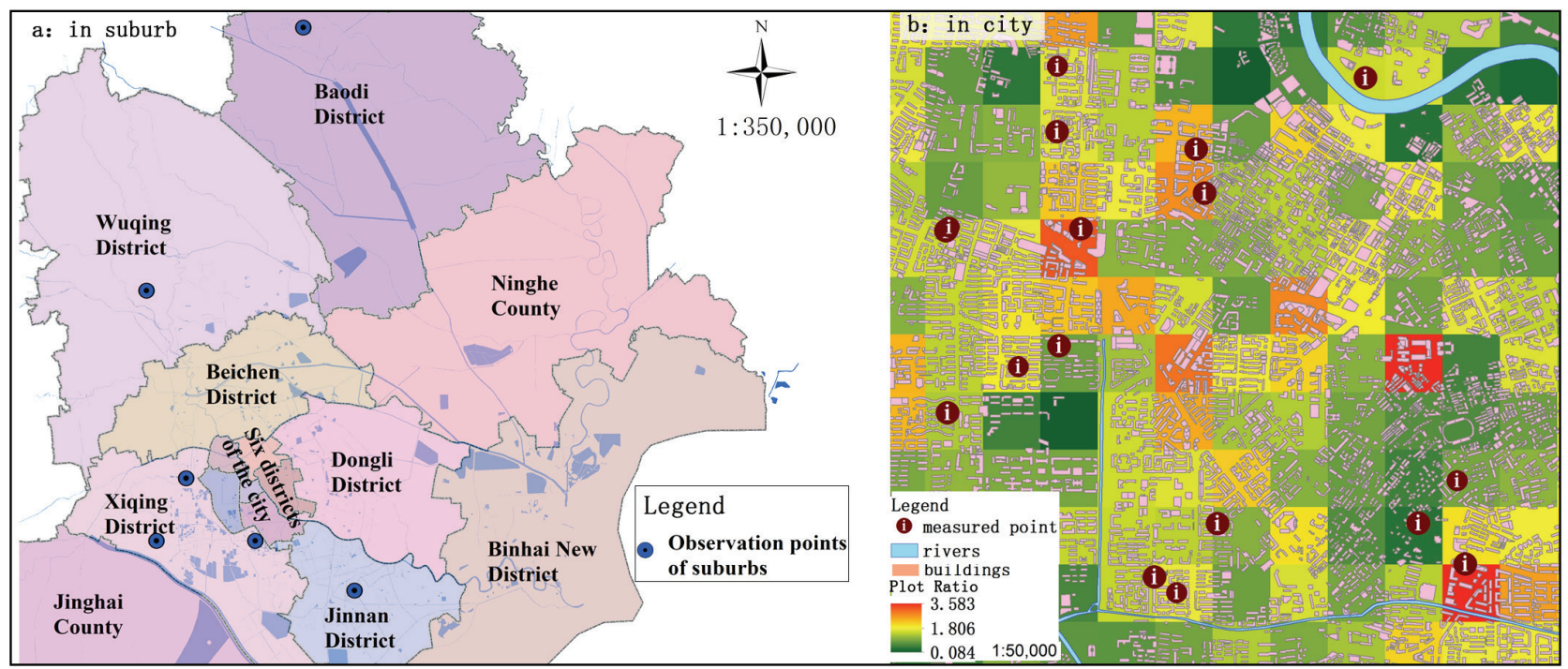

Figure 2 UHI observation points in suburb and city

4 Result analysis and discussion

4.1 Concept and calculation method of core plot ratio 4.1.1 Proposal of the problem

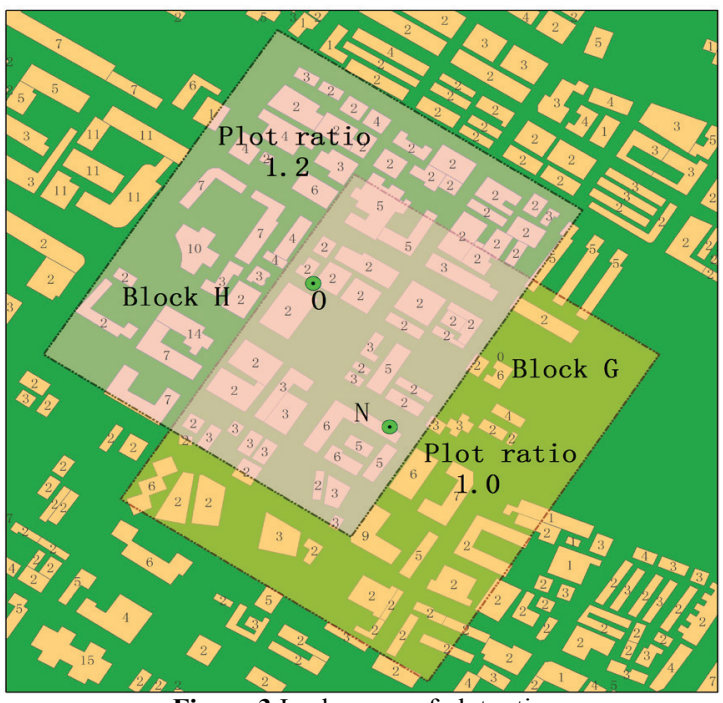

Figure 3 Inadequacy of plot ratio

The planning design generally calculates the plot ratio based on the block. Plot ratio is the ratio of the total construction area to the floor area. The calculation method actually homogenizes the entire block space but ignores the difference among different points in the spatial position; thus, it cannot accurately calculate the resulting difference in space environment effect. On the basis of the influence of plot ratio on UHI shown in Fig. 3, the plot ratio of the block $\mathrm{H}$ is 1,19 , which means the plot ratios of all points in the scope of $\mathrm{H}$ are 1,19. The plot ratios of Points $\mathrm{O}$ and $\mathrm{N}$ are equal to 1,19, but significant differences exist between the two points. As the centre of Block $\mathrm{H}$, Point $\mathrm{O}$ is greatly affected by the plot ratio of $\mathrm{H}$.
$\mathrm{N}$ is the centre of Block $\mathrm{G}$; hence, it is greatly affected by the plot ratio of G. If the UHII of $\mathrm{N}$ is calculated based on the plot ratio of Block $\mathrm{H}$, then it will cause a great error. Therefore, this study proposes the concept of core plot ratio.

\subsubsection{Concept and calculation method of core plot ratio}

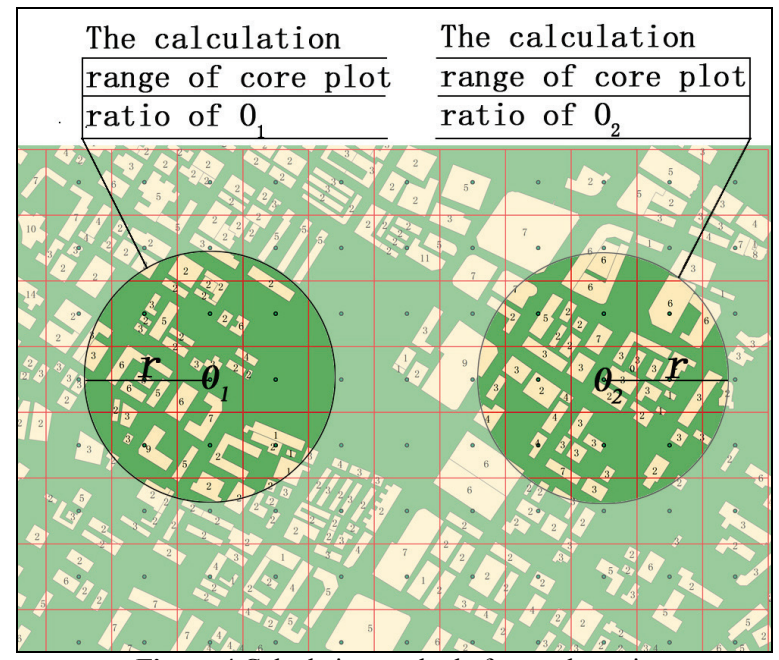

Figure 4 Calculation method of core plot ratio

The core plot ratio of a point in space refers to the ratio of the total construction area to the floor area in a certain range with this point as the core. This ratio is calculated according to the idea of kernel density function to spatially move the domain space units, search the pixels individually based on the grid data format (Fig. 4), and take one point as the centre to draw a circle as the filter window and the average value in the window as the core plot ratio of the point to obtain the core plot ratio 
variation diagram of continuous space change. Its calculation formula can be expressed as

$$
\hat{f}(x)=\frac{1}{n h^{d}} \frac{\sum_{i=1}^{n} K\left(w_{i} x_{i}\right)}{A}
$$

where $K()$ is the kernel density formula, $w_{i}$ is the weight value of the space $i, \mathrm{~A}$ is the area of the filter window, $h$ is the threshold range of space action, $n$ is the number of points within the thresholds, and $d$ is the number of data dimensions. In the core plot ratio calculation, different radii scales of the circles consider various base areas and exert dissimilar influences on the calculation accuracy of UHII.

\subsection{Space scale sensitivity of core plot ratio}

The search circles of different radii are set in accordance with the calculation formula (3) of the scale sensitivity to calculate the space scale sensitivity that is used to evaluate the core plot ratio and reduce the summer heat island. The study area was first resampled into the grid data with a resolution of $1 \mathrm{~m}$. Radii of 90, 120, 150, $120,210,225,230,225,225,270,300$, and $350 \mathrm{~m}$ were then taken to calculate the hourly correlation coefficients between core greening rate and UHII. Finally, the absolute values of the hourly correlation coefficients were summed up to calculate the sensitivity index $S$.

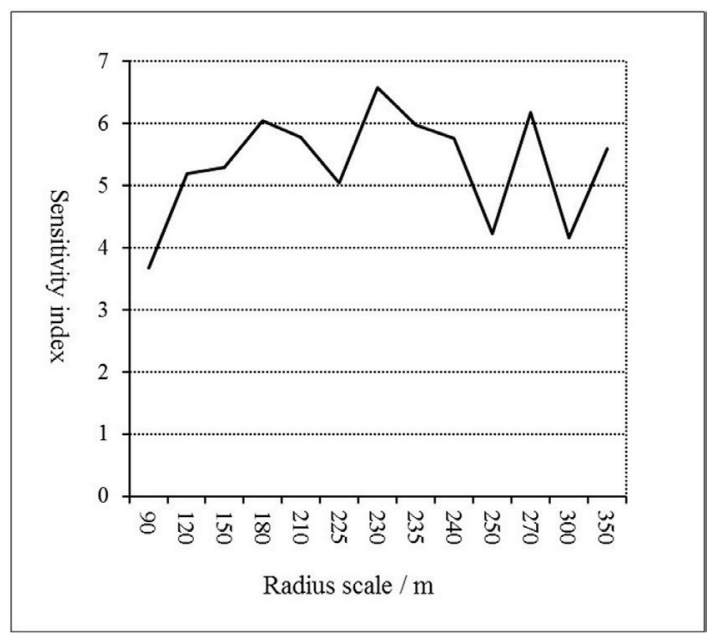

Figure 5 Core plot rate UHI scale sensitivity

The sensitivities $S$ under different space scales were used to draw the scale sensitivity curve of core plot ratio and UHII (Fig. 5). According to Fig. 5, $S$ begins to rise from the radius of $120 \mathrm{~m}$. When the radius reaches $230 \mathrm{~m}$, $\mathrm{S}$ gradually decreases first and then begins to fluctuate after the radius reaches $270 \mathrm{~m}$. The law of space autocorrelation shows that a great scale radius between sampling and proximal points leads to a high building volume. However, when the radius exceeds the maximum value $R$, the irrelevant buildings are covered in the calculation, thereby resulting in fluctuation in the sensitivity index (Fig. 5). Therefore, the core plot ratio can best reflect its influence on UHII when the space search radius is $230 \mathrm{~m}$ (Fig. 6). In other words, the building plot ratio within the circle with a radius of $230 \mathrm{~m}$ has a great influence on UHII of the centre point.

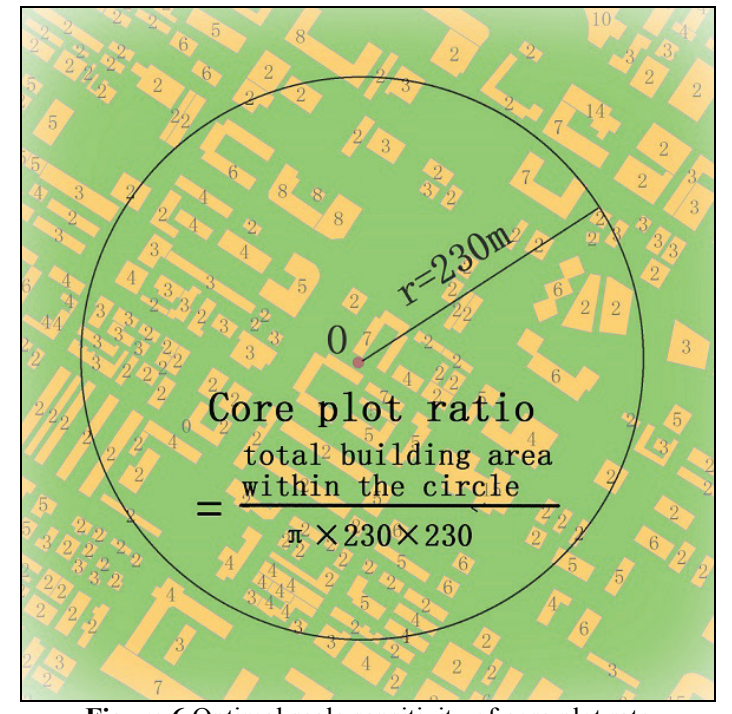

Figure 6 Optimal scale sensitivity of core plot rate

\subsection{UHI change analysis in the daytime under the sensitivity scale \\ 4.3.1 Hourly effect analysis in the daytime}

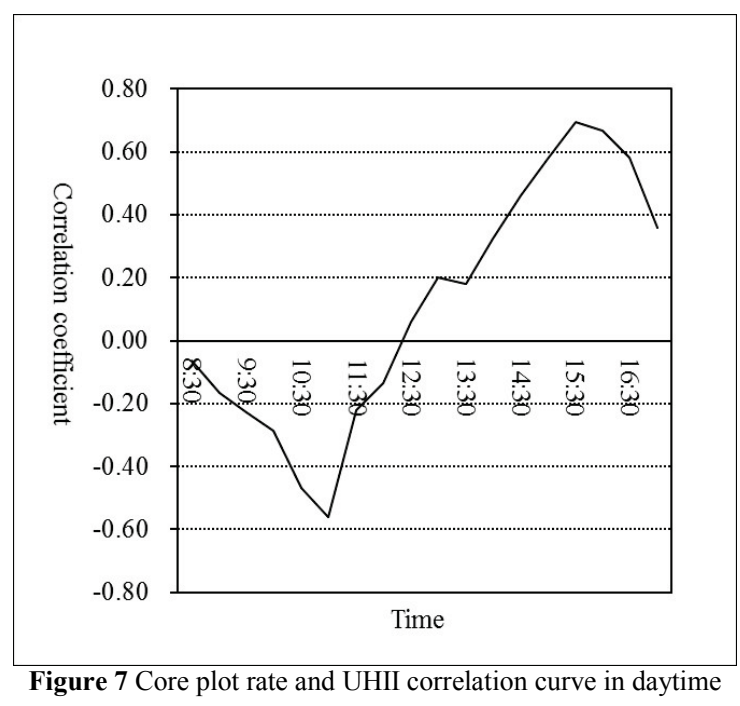

The relevant coefficients need to be calculated and tested, and their correlation and correlation significance should be compared and judged to accurately describe and depict the correlation between core plot ratio and UHII. The core plot ratios and UHII data in half an hour of 18 stations in the city were adopted to construct the original data matrix. SPSS 20 software was used to calculate the hourly correlation coefficients during 8:30 and 17:00. The correlation coefficients were then inspected and judged. Finally, the correlation curve between core plot ratio and UHII in the daytime was drawn with the correlation coefficients as the $y$ axis and the time as the $x$ axis (Fig. 7).

Fig. 7 presents that the correlation between core plot ratio and UHII during 8:30 and 17:00 experiences two stages from negative correlation to positive correlation, with the positive correlation in the afternoon as the primary. In other words, the core plot ratio reduces UHI slightly in the morning and enhances it in the afternoon significantly. The ratio is negatively correlated during 
8:30 and 12:30, with the value changing from low to high and to low again and reaching the peak at 11:00; by contrast, it is positively correlated during 12:30 and 17:00, with the value changing from low to high and to low again and reaching the peak at 15:00.

The test results of the hourly correlation coefficients show that the correlation coefficients during 10:30 and 11:00 exceed the test with the confidence level of 0,05 . In other words, the probability of negative correlation between plot ratio and UHI is as high as $95 \%$. The correlation coefficients during 14:30 and 16:30 exceed the test with the confidence level of 0,05 , which reveals that the probability of positive correlation between plot ratio and UHI is as high as $95 \%$.

\subsubsection{Hourly regression analysis in the daytime}

Further study was conducted on the quantitative correlation between core plot ratio and UHII during 10:30 and 11:00 and during 14:30 and 16:30. MATLAB and SPSS software were used to conduct fitting analysis on 15 linear and nonlinear experiments. The formulas of 15 curves are as follows:

Linear: $y=b+b_{1} x$

Quadratic: $y=b+b_{1} x+b_{2} x^{2}$

Compound: $y=b b_{1}{ }^{x}$

Growth: $y=\mathrm{e}^{\left(b+b_{1} x\right)}$

Logarithmic: $y=b+b_{1} \ln (x)$

Cubic: $y=b+b_{1} x+b_{2} x^{2}+b_{3} x^{3}$

$S: y=\mathrm{e}^{\left(b+\frac{b_{1}}{x}\right)}$

Exponential: $y=b \cdot \mathrm{e}^{\left(b_{1} x\right)}$

Inverse: $y=b+\frac{b_{1}}{x}$

Power: $y=b x^{b_{1}}$

Logistic: $y=\frac{1}{\frac{1}{a}+b\left(b_{1} x\right)}$

Fourier: $y=a+b_{1} \cos (x w)+b \sin (x w)$

Gaussian: $y=a \cdot \mathrm{e}^{-\left(\frac{x-b}{c}\right)^{2}}$

Rational: $y=\frac{a}{x^{2}+b x+b_{1}}$

Sum of Sine: $y=a \sin \left(b x+b_{1}\right)$

where $a, b, b_{1}, b_{2}$ and $b_{3}$ are constants, $x$ is the independent variable, and $y$ is the dependent variable. The function with the best fitting effect was determined after the comparative analysis of $R^{2}$, root-mean-square error, and other parameters. Finally, the fitting formulas of all periods are given in Tab. 1.

The fitting curves imply that UHII is linear with core plot ratio. The UHII in the morning drops with an increase in core plot ratio. An increase in the average core plot ratio by 1 reduces the UHII by $0,76{ }^{\circ} \mathrm{C}$ in the morning. The UHII in the afternoon rises with the increase in core plot ratio. An increase in the average core plot ratio by 1 increases the UHII by $0,97^{\circ} \mathrm{C}$.

Table 1 Regression formula between core plot ratio and UHII

\begin{tabular}{|c|l|c|c|}
\hline Time & \multicolumn{1}{|c|}{ Equation } & $R^{2}$ & $F$ \\
\hline $10: 30$ & $y=-0,72 x+4,17$ & 0,23 & 4,61 \\
\hline $11: 00$ & $y=-0,8 x+4,25$ & 0,32 & 7,28 \\
\hline $14: 30$ & $y=0,78 x+2,13$ & 0,25 & 5,23 \\
\hline $15: 00$ & $y=0,82 x+2,02$ & 0,39 & 10,17 \\
\hline $15: 30$ & $y=1,01 x+1,69$ & 0,52 & 17,62 \\
\hline $16: 00$ & $y=1,21 x+1,37$ & 0,51 & 16,20 \\
\hline $16: 30$ & $y=x+1,63$ & 0,375 & 9,51 \\
\hline
\end{tabular}

\subsection{Effect mechanism analysis}

Compared with the suburbs, a city reflects a smaller amount of solar radiation. The average reflectivity of the cover layer of urban underlying surface is 0,15 , and its reflection coefficient of solar radiation is $10 \%$ to $30 \%$ smaller than that of the suburbs [39]. The temperature rises from 7:00 to 14:00 every day. At this time, the city and the suburbs absorb the heat; however, the largest difference between them is that the 3D structure of urban buildings increases the volume of heat storage. Therefore, UHII is negatively correlated with plot ratio in the morning. After 14:00, with the reduction in solar radiation and the drop in temperature, urban buildings absorb the most heat and the temperature becomes the highest; consequently, they begin to release heat. Plot ratio is naturally reflected to positively enhance UHII in the afternoon.

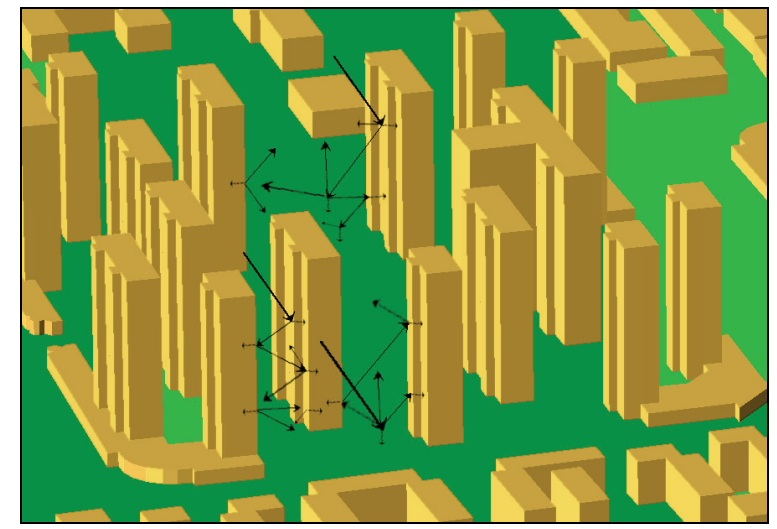

Figure 8 Mechanism of building plot ratio on summer UHI

In the afternoon, plot ratio shows a strong positive correlation with UHII and increases the UHI temperature. The coverage of 3D urban buildings blocks the long-wave radiation and makes it stay near the ground (Fig. 8). 3D buildings in the city make the sky view factor small. The heat stored by the buildings partially transfers to the underlying surface in the form of long wave. After composite superposition of the long wave on the ground, it radiates a large amount of long waves upward. Such long waves are reflected by tall buildings. As a result, the long waves reflected to the sky are limited. The longwave radiation heat near the ground is difficult to release in the sky, which further enhances the UHII, due to the pollution in the high sky and the inverse radiation of aerosol in the atmosphere in the city. 


\subsection{Analysis of the critical value of early warning parameters}

In the urban planning and construction, measures should be taken to avoid the superimposed effect of summer high temperature and high UHII. A very hot temperature is experienced in Tianjin in summer. UHI inevitably intensifies the summer high temperature and causes an adverse effect on the urban living environment. Core plot ratio intensifies UHI in the daytime. An increase in the core plot ratio by 1 promotes the average UHII to increase by $0,97{ }^{\circ} \mathrm{C}$. If the UHI temperature rise is superimposed in different areas of the city, then the UHI caused by the plot ratio in Tianjin reaches the degree of damaging the physical health of humans. Different high-temperature conditions can cause different degrees of influence and damage to human body. The corresponding physical performance is shown in Tab. 2 [40].

Table 2 Human physiological responses to environmental high temperature

\begin{tabular}{|c|c|c|}
\hline $\begin{array}{l}\text { Temperature } \\
{ }^{\circ} \mathrm{C}\end{array}$ & $\begin{array}{c}\text { Physiological } \\
\text { Response }\end{array}$ & Physiological Performance \\
\hline 35 & $\begin{array}{l}\text { Start of the heat } \\
\text { radiation mechanism }\end{array}$ & $\begin{array}{l}\text { At this time, superficial veins begin to distend with perspiration, racing heartbeat, and fast blood } \\
\text { circulation. The temperature needs to be reduced for the elderly and the weak. }\end{array}$ \\
\hline 36 & Level 1 Warning & $\begin{array}{l}\text { The temperature of the human body reduces through sweat evaporation. At this time, some } \\
\text { mineral water containing salt and vitamin needs to be drunk to prevent electrolyte disorder. } \\
\text { Other measures also need to be taken to reduce the temperature. }\end{array}$ \\
\hline 38 & Level 2 Warning & $\begin{array}{l}\text { At this time, the normal body temperature regulation is difficult to ensure through perspiration. } \\
\text { People may feel breathless and fast heart beat. The blood flows to the body surface, thereby } \\
\text { inducing heat dissipation. }\end{array}$ \\
\hline 39 & Level 3 Warning & This level is the dangerous period for the elderly to suffer from cardiac sudden death. \\
\hline 40 & Level 4 Warning & $\begin{array}{l}\text { People should be cautious at this level. High temperature will make people dizzy and even get } \\
\text { sunstroke and shock, especially for children and the elderly. }\end{array}$ \\
\hline
\end{tabular}

On the basis of the temperature in dog days of summer, human physiological response under high temperature, and relevant national regulations (Evaluation Standard for Green Building), this study proposes that in the urban-planning construction, the early warning of the plot ratio on UHII during $14: 30$ and 16:30 is divided into three levels, namely, yellow, orange, and red. A difference of $1,5{ }^{\circ} \mathrm{C}$ exists between two levels, which is also the maximum allowable value of the national green building standard. The summer UHI damage measure reached by the plot ratio can be expressed by the following formula:

$$
f(x)=\bar{a}+\Delta T+b
$$

where $\bar{a}$ is the early warning benchmark of UHI. The average temperature is $32,3{ }^{\circ} \mathrm{C}$ during this period for years. $b$ is the UHI nugget. The geostatistical space analysis and calculation reveal that the average UHI benchmark value in Tianjin is $1,768{ }^{\circ} \mathrm{C} . \Delta T$ is the UHI temperature rise value caused by the plot ratio.

Table 3 Core plot rate alert level and the corresponding UHI temperature rise

\begin{tabular}{|l|c|c|c|}
\hline \multicolumn{1}{|c|}{ Early warning level } & Yellow & Orange & Red \\
\hline $\begin{array}{l}\text { UHI temperature rise } \\
\text { caused by plot ratio }{ }^{\circ} \mathrm{C}\end{array}$ & $1,0 \div 2,5$ & $2,5 \div 4,2$ & $\begin{array}{c}4,2 \text { and } \\
\text { above }\end{array}$ \\
\hline UHI temperature rise $^{\circ} \mathrm{C}$ & 2,7 & 4,2 & 5,7 \\
\hline Reaching temperature $^{\circ} \mathrm{C}$ & 35 & 36,5 & 38 \\
\hline Plot ratio & 1 & 3,2 & 4,15 \\
\hline
\end{tabular}

The calculation result of $f(x)$ presents that the temperatures reaching three warning levels are $35,36,5$ and $38{ }^{\circ} \mathrm{C}$ for yellow, orange, and red, respectively. After the calculation by the regression formula of UHII and core plot ratio in this period, the corresponding plot ratios of three early warning levels are 1,0, 3,2 and 4,15 for yellow, orange, and red, respectively (Tab. 3).
UHII is one of the green building standards and one of the factors affecting the degree of comfort of urban environment. The plot ratio during 14:30 and 16:30 has a negative impact on UHI. High UHII, long effect duration, great damage to the environmental temperature, and significant contribution to the daily average UHII also enhance the daily average UHII. The reduction effect during 9:00 and 11:00 lasts a short period of time, and the effect is relatively weak. However, no regulation is provided on the UHII during $14: 30$ and $16: 30$. If no attention is paid to this issue in planning and construction, then a large number of air conditioners must be used and hot environment circulation must be deteriorated.

\section{Conclusion}

This study proposes the concept of core plot ratio and the measuring method of scale sensitivity and studies the daily variation laws of plot ratio and UHI to define the mechanism of building plot ratio on summer UHI and to provide the scientific quantitative layout basis for planning and designing UHI prevention and control. Remote sensing, measurement, topographic map, and other data are adopted to establish a theoretical model about the response mechanism of the plot ratio on UHI through the fitting and regression analysis by several methods based on the scale theory of geoscience and landscape ecology, reveal its mechanism, and build an early warning parameter system. This study draws the following conclusions:

First, the building plot ratio influences the summer UHI on different scales. The optimal sensitive radius of summer UHI temperature rise caused by core plot ratio is $230 \mathrm{~m}$. This radius is the most effective to control UHI by building plot ratio on this scale.

Second, the relationship between core plot ratio and summer UHI in the daytime shifts from negative correlation to positive correlation. The enhancement 
effect on UHI in the afternoon is greater than the cooling effect in the morning. The influence during 10:30 and $11: 00$ and during $14: 30$ and $16: 30$ is the most significant. Core plot ratio is linear with summer UHI. The regression curve shows that an increase in the average core plot ratio by 1 reduces the UHII by $0,76{ }^{\circ} \mathrm{C}$ in the morning and increases it by $0,97{ }^{\circ} \mathrm{C}$ in the afternoon.

Third, the response mechanism of plot ratio on UHI is mainly due to the heat storage volume and the block to the radiant heat. Buildings of high plot ratio have large $3 \mathrm{D}$ structures, which block the long-wave radiation and heat release. Buildings with large heat storage volumes absorb much heat in the morning and release heat in the afternoon to enhance UHI.

Fourth, a parameter warning system suitable for local UHI control by plot ratio can be established on the basis of the climate in summer, human physiological response under high temperature, and relevant national and regional regulations. This study proposes three levels of early warning in Tianjin in accordance with the temperature in dog days of summer, human physiological response under high temperature, and relevant national regulations. The early warning values of plot ratio are 1,0 , 3,2 and 4,15 for yellow, orange, and red, respectively; the corresponding UHI temperature rise control values are 1, 2,5 and $4,2{ }^{\circ} \mathrm{C}$ for yellow, orange, and red, respectively.

This study provides a sensitive scale reference of the influence of plot ratio on UHI for planning and design and clarifies the variation curve and model of daily plot ratio and UHI. The action mechanism analysis also provides the scientific qualitative explanation, and the established early warning parameter system provides a numerical reference for ensuring comfort, health, and liveability of the planning scheme. However, the hot living environment above the second floor, which has a certain deviation with the actuality, is disregarded due to the lack of detailed observation data of 3D (urban canopy layer) temperature variation of the buildings. Therefore, in the future study, obtaining 3D data to expand the relevant mathematical model by advanced monitoring equipment and accurately reflecting the change in the 3D temperature field will be helpful for recognizing the change law of urban thermal environment, which will also be the study focus in the future.

\section{Acknowledgement}

This study was supported by grants from the National Natural Science Foundation of China (Grant No. 31600571 and 31570703), the China Postdoctoral Fund, the $59^{\text {th }}$ batch (Grant No. 2016M591824), the project of Nanjing Forest Industry University for Good Education Papers (Grant No. 0064).

\section{References}

[1] Howard, L. The climate of London, deduced from Meteorological observations, made at different places in the neighborhood of the metropolis. London: W. Philips, 1818 pp. 20.

[2] Anna, T.; John, P. P.; Giouli, M. Urban heat island intensity: a literature review. // Fresenius Environmental Bulletin. 24, 12B(2015), pp. 4535-4554.
[3] Oliver, B.; Marie-Therese, H; Fred, M. Evaluation of the health-risk reduction potential of countermeasures to urban heat islands. // Energy and Buildings. 114, (2016), pp. 2737. DOI: 10.1016/j.enbuild.2015.06.038

[4] Mohan, M; Kikegawa, Y.; Gurjar, B. R. Assessment of urban heat island effect for different land use-land cover from micrometeorological measurements and remote sensing data for megacity Delhi. // Theoretical and Applied Climatology. 112, 5(2013), pp. 647-658. DOI: 10.1007/s00704-012-0758-z

[5] Guanhua, G.; Zhifeng, W.; Rongbo, X. Impacts of urban biophysical composition on land surface temperature in urban heat island clusters. // Landscape and Urban Planning. 135, 3(2015), pp. 1-10.

[6] Kotharkar, R.; Surawar, M. Land Use, Land Cover, and Population Density Impact on the Formation of Canopy Urban Heat Islands through Traverse Survey in the Nagpur Urban Area, India. // Journal of Urban Planning and Development. 142, 1(2016), pp. 31-43. DOI: 10.1061/(ASCE)UP.1943-5444.0000277

[7] Szegedi, S.; Toth, T.; Kapocska, L. Examinations on the meteorological factors of urban heat island development in small and medium-sized towns in Hungary. // Carpathian journal of earth and environmental sciences. 8, 2(2013), pp. 209-214.

[8] Xu, L. Y.; Xie, X. D.; Li, S. Correlation analysis of the urban heat island effect and the spatial and temporal distribution of atmospheric particulates using TM images in Beijing. // Environmental Pollution. 178, 7(2013), pp. 102114. DOI: 10.1016/j.envpol.2013.03.006

[9] Memon, R. A.; Leung, D. Y. C.; Chunho, L. A review on the generation, determination and mitigation of Urban Heat Island. // Journal of Environmental Sciences. 20, 1(2008), pp. 120-128. DOI: 10.1016/S1001-0742(08)60019-4

[10] Akbari, H.; Kolokotsa, D. Three decades of urban heat islands and mitigation technologies research. // Energy and Buildings. 133, 9(2016), pp. 834-842. DOI: 10.1016/j.enbuild.2016.09.067

[11] Wenhui, K.; Yue, L.; Yinyin, D.; Wenfeng, C.; Guangsheng C.; Chengfeng, Gao.; Tianrong, Y.; Jiyuan L.; Renhua Z. What are hot and what are not in an urban landscape: quantifying and explaining the land surface temperature pattern in Beijing, China. // Landscape Ecology. 30, 2(2014), pp. 357-373.

[12] Wang, W.; Wen, Z.; Edward, Y. Y.; Yong X. Urban heat islands in Hong Kong: statistical modeling and trend detection. // Natural Hazards. 83, 2(2016), pp. 885-907. DOI: 10.1007/s11069-016-2353-6

[13] Hamdi, R.; Schayes, G. Sensitivity study of the urban heat island intensity to urban characteristics. // International Journal of Climatology. 287(2008), pp. 973-982. DOI: 10.1002/joc. 1598

[14] Yunhao, C.; Ji, Z.; Edu, G.; Wei, M.; Wenfeng, Z. Remote Sensing - Spatial Form and Thermal Radiation Directional Simulation of Urban Space Thermal Environment. Beijing : Science Press, 2014.

[15] Chun, B.; Guldmann, J. M. Spatial statistical analysis and simulation of the urban heat island in high-density central cities. // Landscape and Urban Planning, 125, 3(2014), pp. 76-88. DOI: 10.1016/j.landurbplan.2014.01.016

[16] Yaning, G.; Xinliang, X.; Jing, L.; Hongyan, C.; Xuexia, Z. Study on the influence of urban building density on the heat island effect in Beijing. // Journal of Geo-information Science. 18, 12(2016), pp. 1698-1706.

[17] Nassar, A. K.; Blackburn, G. A.; Whyatt, J. D. Dynamics and controls of urban heat sink and island phenomena in a desert city: Development of a local climate zone scheme using remotely-sensed inputs. // International Journal of Applied Earth Observation and Geoinformation. 51, 5(2016), pp. 76-90. DOI: 10.1016/j.jag.2016.05.004 
[18] Rao, P. K. Remote sensing of 'urban heat islands' from an environment satellite. // Bulletin of the American Meteorological Society. 53, (1972), pp. 647-648.

[19] Yang, P.; Ren, G.; Weidong, L. Spatial and Temporal Characteristics of Beijing Urban Heat Island Intensity. // Journal of applied meteorology and climatology. 52, 8(2013), pp. 1803-1816. DOI: 10.1175/JAMC-D-12-0125.1

[20] Weifeng, L.; Qiwen, C.; Kun, L.; Jiansheng, W. Linking potential heat source and sink to urban heat island: Heterogeneous effects of landscape pattern on land surface temperature. // Science of the Total Environment. 586, 1(2017), pp. 457-465.

[21] Liguang, L.; Shenlai, X.; Hongbo, W. Study on urban thermal environment based on meteorological data. Beijing : Chemical Industry Press, 2014.

[22] Boehme, P.; Berger, M.; Massier, T. Estimating the building based energy consumption as an anthropogenic contribution to urban heat islands. // Sustainable Cities and Society. $\quad 19, \quad 5(2015), \quad$ pp. 373-384. DOI: 10.1016/j.scs.2015.05.006

[23] Stewart, I. D.; Oke, T. R.; Krayenhoff, E. S. Evaluation of the 'local climate zone' scheme using temperature observations and model simulations. // International Journal of Climatology. 34, 4(2014), pp. 1062-1080. DOl: 10.1002/joc.3746

[24] Radhi, H.; Sharples, S.; Assem, E. Impact of urban heat islands on the thermal comfort and cooling energy demand of artificial islands - A case study of AMWAJ Islands in Bahrain. // Sustainable Cities and Society. 19, 7(2015), pp. 310-318. DOI: 10.1016/j.scs.2015.07.017

[25] Bakarman, M. A.; Chang, J. D. The Influence of Height/width Ratio on Urban Heat Island in Hot-arid Climates. // Procedia Engineering. 118, 8(2015), pp. 101108. DOI: 10.1016/j.proeng.2015.08.408

[26] Huanchun, H.; Yingxia, Y.; Hongyuan, L.; Suqin H.; Yuqiang Z. An Analysis of Landscape Scale Response Mechanism between building density and summer urban heat island Based on GIS and RS Based on GIS and RS. // Planner. 31, 12 (2015), pp. 101-106.

[27] Wang, X.; Gong, Y. The impact of an urban dry island on the summer heat wave and sultry weather in Beijing City. // Chinese Science Bulletin. 55, 16(2010), pp. 1657-1661. DOI: 10.1007/s11434-010-3088-5

[28] Kim, Y.; Baik J. Spatial and Temporal Structure of the Urban Heat Island in Seoul. // Journal of Applied Meteorology. 44, 5(2005), pp. 591-605. DOI: 10.1175/JAM2226.1

[29] Sirodoev, I.; Cheval, S.; Dumitrescu, A.; Merciu, C.; Vaidianu, N.; Paraschiv, M.; Schvab, A.; Saghin, I.; Prefac, Z. Contribution of the built-up space to the creation of urban heat island in Bucharest municipality. // Journal of Environmental Protection \& Ecology. 16, 4(2015), pp. 1337-1343.

[30] Jiacong, H.; Qijiang Z. Urban Heat Island: Progress of the Field. // Journal of Beijing Normal University (Natural Science). 46, 2(2010), pp. 186-193.

[31] Oke, T. R. City Size and the Urban Heat Island. // Atmospheric Environment. 7, 8(1976), pp. 769-779. DOI: 10.1016/0004-6981(73)90140-6

[32] Liguang, L.; Hongbo, W.; Qingyu, J.; Guohong, L.; Xiaoying, W. Urban heat island intensity and its grading in Liaoning Province of Northeast China. // Chinese Journal of Applied Ecology. 23, 5 (2012), pp. 1345-1350.

[33] Kim, Y. H.; Baik, J. J. Maximum urban heat island intensity in Seoul. // Journal of applied meteorology, 41, 6(2002), pp. 651-659. DOI: 10.1175/15200450(2002)041<0651:MUHIII>2.0.CO;2
[34] Liu, J. H. On the Methods of the Expressing the Urban Heat-island Intensity. // Geographical Research. 41, 6(2002), pp. 651-659.

[35] Borruso, G. Network Density and the Delimitation of Urban Areas. // Transactions in GIS. 7, 2(2003), pp. 177191. DOI: 10.1111/1467-9671.00139

[36] Bojie, F.; Dingli, C. Principle and Application of Landscape Ecology. Peking: Science Press, 2011. pp. 4449.

[37] Lun, G.; Wenfeng, Z.; Fan, H. Localization or Globalization? Determination of the Optimal Regression Window for Disaggregation of Land Surface Temperature. // IEEE Transactions on Geoscience and Remote Sensing. 55, 1(2017), pp. 477-490. DOI: 10.1109/TGRS.2016.2608987

[38] Xiaowen, L.; Chunxiang, C.; Chaoyi, C. The First Law of Geography and Spatial-Temporal Proximity. // Nature. 29, 2(2007), pp. 69-71.

[39] Jiaping, L. The Physics Environmental of the City. Beijing: China Construction Industry Press, 2011, pp. 50.

[40] Zhian. H.; Shali, W. Physiology. Beijing: Science Press, 2014, pp. 159-192.

\section{Authors' addresses}

\section{Huanchun Huang, Ph.D.}

School of Architecture and Urban Planning, Nanjing University, College of Landscape Architecture, Nanjing Forestry University, No. 159 Lonpan Road, Nanjing, 210037, Jiangsu, P. R. China E-mail: huangyanlin2010@163.com.cn

\section{Yingxia Yun, Ph.D., Professor}

School of Architecture, Tianjin University,

No. 92 Weijin Road, Nankai District, 300072, Tianjin, P. R. China E-mail: yunyx@126.com.cn

\section{Jiangang $\mathrm{Xu}$, Master, Professor}

(Corresponding author)

School of Architecture and Urban Planning, Nanjing University, 22 Hankou Road, Gulou District, Nanjing, Jiangsu Province, 210093, Jiangsu Province, P. R. China

ZIP code: 210093

E-mail: xjg129@sina.com

\section{Rong Huang, Bachelor}

College of Landscape Architecture, Nanjing Forestry University, No.159 Lonpan Road, Nanjing, 210037, Jiangsu, P. R. China E-mail: 453969465@qq.com.cn

\section{Jing Fu, Ph.D.}

Graduate School of Global Environmental Studies, Kyoto University,

Yoshida-honmachi, Sakyo-ku, Kyoto 606-8501, Japan

E-mail: fu.28z@hotmail.com

\section{Kaidi Huang, Bachelor}

College of Landscape Architecture, Nanjing Forestry University, No.159 Lonpan Road, Nanjing, 210037, Jiangsu, P. R. China. E-mail: 790528165@qq.com.cn 